\title{
STRATEGI PROGRAMMING RADIO KOMUNITAS \\ (Studi Kasus Radio Komunitas Seni Budaya (RKSB) Ujung Berung Kota Bandung)
}

\author{
Reni Nuraeni, Fauzia Octaviani, Agus Aprianti \\ Program Studi Ilmu Komunikasi Fakultas Komunikasi dan Bisnis Telkom University \\ Jl. Telekomunikasi Terusan Buah Batu Bandung
}

\begin{abstract}
ABSTRAK
Penelitian ini bertujuan untuk menganalisa strategi programming Radio Komunitas Seni Budaya. Penelitian ini berfokus pada strategi programming program di Radio Komunitas Seni Budaya. Strategi yang digunakan untuk mendukung penelitian ini adalah strategi programming Radio Komunitas Seni Budaya (RKSB) Ujung Berung Bandung. Hasil penelitian dan analisis yang dilakukan menunjukkan bahwa Radio Komunitas Seni Budaya belum sempurna dalam menerapkan teori tentang strategi programming menurut Sydney tersebut. Dalam Kesesuaian, program disiarkan per-tiga jam dan prime time terletak pada jam 15:00 - 18:00 dan setelah jam 19:00. Dalam Membangun Kebiasaan, Radio Komunitas Seni Budaya melakukan pemberitahuan jadwal program yang disiarkan dengan diiringi jingle. Dalam Pengontrolan Aliran Pendengar, Radio Komunitas Seni Budaya menyebutkan nama pendengar yang mengirim SMS atau menelepon saat program mengudara. Dalam Pemeliharaan Sumber Daya Program, materi program diperoleh dari sumbangan masyarakat Ujungberung. Dalam Daya Tarik yang Luas, Radio Komunitas Seni Budaya menyajikan program live on air. Kesimpulan dari penelitian ini, strategi programming ini dirasa belum tepat untuk diterapkan di radio komunitas karena sebuah radio komunitas harus memiliki sumber daya manusia dan perlengkapan yang memadai untuk bisa merumuskan strategi program yang sempurna.
\end{abstract}

Kata kunci: Strategi Programming, Radio Komunitas, Program 


\section{Pendahuluan}

Pada tataran ideal, media lokal, termasuk di antaranya radio siaran, memiliki fungsi ekonomi, sosial, politik, serta kebudayaan bagi sebuah daerah. Media lokal merupakan sarana pengembangan nilainilai dan potensi lokal, termasuk kebudayaan lokal. Sebuah kebudayaan lokal dapat dikatakan berkembang bila mendatangkan manfaat bagi masyarakatnya dan memberi kesadaran tentang manfaat tersebut pada masyarakatnya (Yudhapramesti dan Fadilah, 2011: 4).

Lembaga Penyiaran Komunitas merupakan lembaga penyiaran yang didirikan oleh komunitas tertentu dan menjadi hak milik komunitas tersebut. Lembaga penyiaran komunitas didirikan tidak untuk mencari keuntungan, melainkan untuk mendidik dan memajukan masyarakat dalam mencapai kesejahteraan dengan menyajikan program-program budaya, pendidikan, dan informasi untuk komunitasnya atau masyarakat setempat.

Di Kota Bandung, tepatnya di Ujungberung, berdiri sebuah radio komunitas yang menamakan dirinya "Radio Komunitas Seni Budaya" yang berorientasi khusus seni dan budaya Sunda. Awal berdirinya stasiun radio ini digagas oleh Novi Sumengkar, Deden Kusnia, dan Deddy Suhendar. RKSB adalah singkatan dari Radio Komunitas Seni Budaya, merupakan nama udara yang baru untuk Radio Maja 107,7 FM Ujungberung, Bandung.

Persaingan industri media, isu kualitas program menjadi semakin mengemuka, karena kualitas dipandang sebagai suatu syarat penting untuk memenangkan persaingan tersebut dalam memenangkan konsumen. Untuk radio komunitas terutama, bagaimana radio tersebut tetap mempunyai daya saing sedangkan tidak hanya bersaing dengan radio komunitas lainnya, tetapi juga dengan radio swasta dan komersial yang lebih dikenal oleh pendengar.

Sebuah radio yang baik, baik radio komunitas ataupun radio swasta, adalah radio yang mampu menghasilkan program siaran yang sesuai dengan kebutuhan khalayak sasaran. Pemrograman penting untuk sebuah stasiun radio, terutama radio komunitas, karena pemrograman yang baik dan terencana dengan matang akan menghasilkan program siaran yang baik dan memenuhi kebutuhan khalayaknya. Berdasarkan latar belakang inilah peneliti merasa bahwa strategi pemrograman yang dijalankan oleh Stasiun Radio Komunitas Seni Budaya Ujungberung tersebut menarik untuk diteliti.

Berdasarkan uraian latar belakang penelitian yang telah dikemukakan di atas, maka fokus penelitian yang akan dibahas dalam penelitian ini adalah langkah-langkah apa saja yang dilakukan oleh Radio Komunitas Seni Budaya Ujungberung dalam mempertahankan eksistensinya dan bagaimana strategi pemrograman yang dilakukan oleh Radio Komunitas Seni Budaya Ujungberung dalam membuat program-program yang dibutuhkan dan digemari oleh masyarakat Ujungberung. 
Berdasarkan fokus penelitian tersebut, maka tujuan dari penelitian ini adalah untuk mengetahui langkah-langkah apa saja yang dilakukan oleh Radio Komunitas Seni Budaya Ujungberung dalam mempertahankan eksistensinya dan untuk mengetahui bagaimana strategi pemrograman yang dilakukan oleh Radio Komunitas Seni Budaya Ujungberung dalam membuat program-program yang dibutuhkan dan digemari oleh masyarakat Ujungberung.

Adapun metode penelitian yang digunakan adalah metode kualitatif dengan pendekatan studi kasus. Kesimpulan dari studi kasus yang didapatkan dari penelitian tidak berlaku secara umum, tetapi hanya terbatas pada kasus-kasus tertentu yang sedang diteliti pada objek tertentu atau di perusahaan yang bersangkutan. Dalam kaitannya dengan penelitian ini, peneliti menggali secara mendalam tentang strategi programming di Radio Komunitas Seni Budaya Ujungberung dalam membuat program-program yang dibutuhkan dan digemari oleh masyarakat Ujungberung.

\section{Kajian Pustaka}

\subsection{Definisi Komunikasi}

Menurut Hovland (dalam Effendy, 2009:10) ilmu komunikasi adalah upaya yang sistematis untuk merumuskan secara tegar asas-asas penyampaian informasi serta pembentukan pendapat dan sikap.

\subsection{Strategi Pemrograman}

Aktivitas pemrograman memerlukan strategi dan taktik. Strategi pemrograman berguna untuk menetapkan apa yang harus dilakukan untuk mecapai misi, visi, dan tujuan dari sebuah stasiun radio dengan segala kelebihan dan kekurangan yang dimiliki oleh stasiun radio tersebut. Terkait dengan strategi pemrograman, maka stasiun radio membuat program-program yang dapat memenuhi kebutuhan dan keinginan audien, dimana dengan adanya strategi ini maka penentuan program-program yang sesuai dan menarik audien akan jauh lebih mudah.

Adapun yang dimaksud dengan strategi adalah perencanaan dan pengarahan suatu operasi dalam skala besar. Dalam pemrograman, operasi tersebut mengacu kepada keseluruhan penjadwalan suatu stasiun penyiaran dan cable system.

Menurut Sydney dalam buku Eastman (2013:18) yang berjudul Media Programming: Strategies \& Practices, strategi radio siaran mencakup lima elemen yang perlu diperhatikan dalam melakukan strategi programming, yaitu:

1. Compatibility (Kesesuaian) 
Strategi kesesuaian adalah kesesuaian penjadwalan, pemilihan tipe program, dan pokok masalah terhadap kebutuhan khalayak pendengar. Personil-personil stasiun pendengar harus mengetahui komunitas yang dituju, sesuai dengan jadwal program yang mereka rancang. Dalam hal ini perlu dipertimbangkan siapa pendengar dalam setiap bagian waktu, dan apa yang kemungkinan besar sedang dikerjakan oleh pendengar yang ada pada saat itu. Sebuah program harus disusun berdasarkan kegiatan sehari-hari audiensnya. Stasiun radio harus mengetahui rutinitas audiens. Ini diperlukan sebagai acuan untuk menjalankan program. Salah satu cara untuk mengetahui hal-hal tersebut adalah dengan melakukan riset audiens.

\section{Habit Formation (Membangun Kebiasaan)}

Semakin lama waktu pendengar mengikuti proram, maka akan berdampak pada lamanya pemasang iklan untuk melakukan promosi. Selain itu juga dapat berfungsi sebagai acuan dalam merencanakan program-program acara yang baru akan dibuat. Masing-masing radio harus bisa membangun kebiasaan mendengarkan target pendengarnya. Tidak jarang pada pembentukan ini timbul sikap fanatik dari khalayak terhadap suatu program acara, sehingga khalayak tidak akan meninggalkan program acara yang disiarkan.

3. Control of Audience Flow (Mengontrol Aliran Pendengar)

Sebisa mungkin untuk memaksimalkan jumlah pendengar dan meminimalisir jumlah pendengar yang berpindah gelombang ke radio siaran lain. Caranya dapat dilakukan dengan metode countering (menyajikan program acara yang berbeda dengan radio siaran lain) atau menggunakan metode blunting (menyajikan program acara seupa atau mirip dengan radio siaran lain)

4. Conservation of Program Resources (Pemeliharaan Sumber Daya Program)

Jam siar pada radio dilakukan terus menerus sepanjang hari, oleh karena itu ketersediaan materi dan sumber daya lainnya yang mendukung program harus benar-benar diperhitungkan. Berbagai upaya harus dilakukan agar materi yang terbatas dapat digunakan sebagai bahan siaran sepanjang hari, misalnya dengan mengemas ulang suatu materi dengan menggunakan pendekatan dan cara penyajian yang berbeda.

5. Bredth of Appeal (Daya Tarik yang Luas)

Radio siaran harus memperhatikan perbedaan minat dan kesukaan dari para pendengarnya. Sehingga harus diupayakan program-program acara yang menarik, serta dapat mengakomodir semua minat dan kesukaan pendengar. Program acara yang disiarkan dapat menjangkau khalayak luas, baik secara teknis maupun sosial. Namun demikian, hal ini 
bergantung pada status organisasi radio dan tujuan yang ingin dicapai melalui program acara yang disiarkan.

\section{Pembahasan}

\subsection{Strategi Kesesuaian (Compatibility)}

Dalam membuat programnya, Radio Komunitas Seni Budaya menyesuaikan dengan visi dan misi dari radio komunitas tersebut, lalu selanjutnya program akan diisi dengan persentasi dari seni yang ada di sekitar wilayah Radio Komunitas Seni Budaya, yaitu wilayah Ujungberung. Jam siaran untuk program tradisi terkadang lebih dari jam siar seharusnya. Hal ini dikarenakan program tradisi disesuaikan dengan kawasan. Kawasan Bandung Timur, khususnya Ujungberung merupakan kawasan seni budaya tradisi. Oleh karena itu, pendengar terkadang meminta program tersebut agar dilebihkan jam siarnya.

Penentuan penjadwalan program di Radio Komunitas Seni Budaya dilihat dari kesiapan sisi sumber daya manusianya, seperti penyiar. Selain itu juga dilihat dari sisi psikologis pendengarnya, program untuk pagi hari, siang hari, sore hari, dan malam hari pantasnya program yang bagaimana dan seperti apa. Lalu, sistem penentuan penjadwalan program dibuat per-tiga jam.

Selain penentuan penjadwalan program, pemilihan tipe program juga penting dalam strategi program radio. Menentukan tipe program yang dibutuhkan oleh masyarakat dan pendengar merupakan acuan untuk membuat sebuah program radio. Penggiat sebuah stasiun radio harus mengetahui tipe program apa yang dibutuhkan dan sesuai dengan rutinitas pendengarnya agar pelaksanaan program sesuai dengan apa yang sudah dirancang.

Radio Komunitas Seni Budaya memiliki berbagai jenis program acara yang berbeda sesuai dengan segmentasi dan targeting yang telah ditentukan. Konsep program di Radio Komunitas Seni Budaya terdiri dari dua, yaitu pelestarian dan pengembangan, dengan format on air dan live on air. Program yang dibuat oleh Radio Komunitas Seni Budaya yang paling utama adalah program tradisi dan temporer. Tujuan dari program-program tersebut adalah agar masyarakat yang tidak tahu tradisi menjadi tahu apa itu tradisi, khususnya budaya dan tradisi Sunda.

Program-program di Radio Komunitas Seni Budaya mencoba untuk sama dengan radio komersil, sehingga mungkin program-program yang ada di Radio Komunitas Seni Budaya sekarang sama dengan radio komersil. Untuk persentasi programnya, Radio Komunitas Seni Budaya lebih mengutamakan di hiburan dan live on air, 75\% untuk siaran biasa (hiburan) dan 25\% untuk siaran live on air. Persentase program di Radio Komunitas Seni Budaya hampir 90\% di hiburan karena Radio 
Komunitas Seni Budaya berorientasi di seni dan budaya, sedangkan untuk berita dan yang lainnya persentasenya sangat kecil.

Radio Komunitas Seni Budaya menentukan semua kalangan sebagai pendengarnya. Segmentasi dan target pendengar Radio Komunitas Seni Budaya mencakup semua kalangan dan usia, mulai dari anak-anak hingga orang tua. Radio Komunitas Seni Budaya memposisikan dirinya sebagai radio yang tidak membatasi.

\subsection{Strategi Membangun Kebiasaan (Habit Formation)}

Pembentukan kebiasaan di sini adalah membentuk kebiasaan mendengarkan yang dihasilkan dari adanya penjadwalan program acara melalui prediksi yang seksama. Oleh karena itu, penyajian setiap program acara dilakukan secara rutin selalu sama waktunya pada jangka waktu tertentu. Strategi yang dilakukan untuk membangun kebiasaan ini adalah dengan pembuatan adlips dan pembuatan rundown. Dengan adanya adlips akan menjadikan pendengar selalu ingat dengan program-program yang ada, dan rundown adalah salah satu acuan bagi penyiar untuk menyiarkan secara tepat sekuen-sekuen pada sebuah program dengan tujuan pendengar akan terbiasa dengan alur penyajian program yang disiarkan (Eastman \& Ferguson, 2013: 19).

Radio Komunitas Seni Budaya memiliki strateginya sendiri dalam membangun kebiasaan pendengarnya. Untuk membangun kebiasaan masyarakat Ujungberung dan komunitas pendengar Radio Komunitas Seni Budaya, para penyiar selalu memberitahukan kepada pendengar mengenai jadwal program-program Radio Komunitas Seni Budaya yang akan mengudara nanti dengan diiringi jingle radio yang menarik, sehingga pendengar akan ingat dengan apa yang disampaikan oleh penyiar saat itu. Jingle tersebut berbentuk informasi berisikan pemberitahuan kepada para pendengar tentang hari, tanggal dan jam dari sebuah program yang akan disiarkan dengan iringan atau backsound lagu dari program yang akan disiarkan tersebut.

Strategi lainnya adalah dengan selalu memutarkan lagu-lagu dengan jadwal yang sama dalam setiap program yang disiarkan oleh Radio Komunitas Seni Budaya. Tujuannya agar pendengar mudah mengingat lagu tersebut biasanya diputar saat program apa dan jam berapa program tersebut biasanya disiarkan. Sehingga pendengar akan mengingat jadwal-jadwal dan nama-nama program di Radio Komunitas Seni Budaya dan akan menjadi kebiasaan dari pendengar tersebut untuk mendengarkan program-program Radio Komunitas Seni Budaya sesuai dengan jadwalnya. 
Strategi membangun kebiasaan yang dilakukan oleh Radio Komunitas Seni Budaya dapat dibilang cukup berhasil. Walaupun tidak terstruktur, namun secara tidak langsung Radio Komunitas Seni Budaya memiliki adlips dan rundown untuk membangun kebiasaan pendengarnya.

\subsection{Strategi Pengontrolan Aliran Pendengar (Control of Audience Flow)}

Sebagian besar pendengar memiliki kebiasaan untuk berpindah saluran saat sebuah program telah selesai mengudara. Biasanya, perpindahan pendengar terhadap satu saluran ke saluran lain ini terjadi pada saat program yang satu berganti ke program berikutnya. Setiap stasiun radio harus melakukan pengontrolan aliran pendengar untuk memaksimalkan jumlah pendengar dari satu pogram ke program acara berikutnya. Selain itu, juga untuk meminimalisir jumlah pendengar yang berpindah saluran ke radio lainnya.

Dalam mengontrol aliran pendengarnya, Radio Komunitas Seni Budaya tidak melakukan metode menyajikan program yang berbeda dengan radio siaran lain (countering) atau menyajikan program acara serupa atau mirip dengan radio siaran lain (blunting), tetapi Radio Komunitas Seni Budaya memiliki strateginya sendiri dalam mengontrol aliran pendengarnya.

Banyak cara yang dilakukan oleh Radio Komunitas Seni Budaya untuk mengontrol aliran pendengarnya. Cara-cara tersebut diantaranya adalah dengan mengadakan talkshow, melakukan kunjungan langsung kepada pendengar, dan bahkan melakukan perekrutan dari pendengar untuk menjadi penyiar di Radio Komunitas Seni Budaya. Selain itu, Radio Komunitas Seni Budaya juga melakukan pendekatan secara personal kepada pendengarnya.

Pengontrolan aliran pendengar juga dilakukan oleh Radio Komunitas Seni Budaya dengan disiplinnya seorang penyiar pada setiap program di Radio Komunitas Seni Budaya agar programprogram di Radio Komunitas Seni Budaya tetap berjalan sesuai dengan yang telah dirancang. Sehingga pendengar akan bertahan dari satu program ke program acara yang berikutnya tanpa berpindah saluran radio apabila penyiar favorit mereka tetap berada di program favorit mereka. Selain itu, mengontrol aliran pendengar juga dilakukan dengan menyiarkan program sesuai dengan minat tertinggi para pendengar Radio Komunitas Seni Budaya.

Radio Komunitas Seni Budaya memang sudah melakukan strategi pengontrolan aliran pendengar semaksimal mungkin untuk meminimalisir jumlah pendengar yang berpindah saluran, seperti yang telah dijelaskan di atas. Tetapi dengan melihat realita yang ada, jangkauan siaran yang dimiliki oleh Radio Komunitas Seni Budaya terbatas dan banyaknya jumlah radio komersil di Bandung, tidak memungkiri bahwa pendengar Radio Komunitas Seni Budaya akan berpindah saluran apabila pendengar sudah berada di luar batas dari jangkauan siaran Radio Komunitas Seni Budaya dan apabila 
pendengar sudah mulai bosan mendengarkan program yang sedang mengudara di Radio Komunitas Seni Budaya.

\subsection{Strategi Pemeliharaan Sumber Daya Program (Conservation of Program Resources)}

Mengingat terbatasnya sumber daya yang dimiliki oleh sebuah radio komunitas, setiap sumber daya yang telah dimiliki oleh radio komunitas baiknya dipelihara sehingga dapat digunakan untuk jangka waktu yang lama. Seperti radio komunitas pada umumnya, Radio Komunitas Seni Budaya pun memiliki keterbatasan dalam sumber dayanya. Maka dari itu, Radio Komunitas Seni Budaya memelihara semaksimal mungkin sumber daya yang dimilikinya, baik sumber daya teknis maupun sumber daya manusianya.

Dalam memelihara sumber daya yang dimilikinya, Radio Komunitas Seni Budaya memiliki strateginya sendiri. Untuk pemeliharaan sumber daya program, Radio Komunitas Seni Budaya melakukan evaluasi alat dan evaluasi personil setiap tiga bulan sekali dan melakukan perencanaan untuk tiga bulan selanjutnya setelah evaluasi tersebut. Dan untuk pemeliharaan sumber daya manusianya, Radio Komunitas Seni Budaya memberikan kebebasan kepada para sumber daya manusianya untuk mengelola radio komunitas tersebut agar para SDM, khususnya penyiar, bertahan di Radio Komunitas Seni Budaya.

Untuk peralatan yang bersifat teknis, pemeliharaan dilakukan secara bersama oleh pengelola Radio Komunitas Seni Budaya, crew, dan komunitas. Sedangkan untuk memperbaiki peralatan yang rusak dilakukan dengan bantuan iuran dari para komunitas.

Untuk materi siaran, Radio Komunitas Seni Budaya mendapatkan sumbangan dari masyarakat Ujungberung, para penggiat Radio Komunitas Seni Budaya dan komunitas-komunitasnya.

Strategi yang dilakukan Radio Komunitas Seni Budaya dalam memelihara sumber daya programnya sudah cukup maksimal. Pemeliharaan sumber daya program yang dilakukan oleh Radio Komunitas Seni Budaya telah mencapai maksud dari teori yang telah dijelaskan sebelumnya. Penyimpanan sumber-sumber program yang dilakukan oleh Radio Komunitas Seni Budaya membuat sumber-sumber program tersebut dapat digunakan untuk jangka waktu yang lama dan dapat dipakai lagi suatu saat nanti.

\subsection{Strategi Daya Tarik yang Luas (Bredth of Appeal)}

Radio Komunitas Seni Budaya pun berusaha menyajikan program-program yang menarik untuk pendengarnya. Radio Komunitas Seni Budaya berusaha membuat program yang berbeda dari program-program yang sudah ada di radio komunitas lainnya untuk menarik minat pendengar. 
Diperlukan strategi daya tarik yang luas untuk sebuah radio komunitas dalam membuat program yang menarik untuk mendapatkan dan mempertahankan pendengarnya.

Strategi daya tarik yang luas yang dilakukan oleh Radio Komunitas Seni Budaya adalah dengan mempertajam program unggulan yang mempunyai ciri khas dan membedakan program tersebut dari program radio komunitas yang lainnya, yaitu program live on air. Program live on air merupakan program yang menarik untuk pendengar dan menjadi ciri khas dari Radio Komunitas Seni Budaya karena pada program tersebut ada grup musik yang tampil secara live di padepokan studio Radio Komunitas Seni Budaya dan disiarkan secara on air kepada pendengar. Program live on air tersebut dapat menarik minat pendengar Radio Komunitas Seni Budaya. Hal tersebut terbukti dari jumlah SMS dan telepon yang masuk saat program tersebut sedang mengudara.

Radio Komunitas Seni Budaya sudah melakukan strategi daya tarik yang luas semaksimal mungkin untuk menarik minat pendengar. Namun karena radio tersebut merupakan radio komunitas, maka jarak siarannya hanya untuk masyarakat sekitar daerah radio komunitas tersebut, yaitu Ujungberung. Sehingga program menarik yang dibuat oleh Radio Komunitas Seni Budaya adalah berdasarkan minat dan kesukaan masyarakat Ujungberung.

\section{Simpulan}

Berdasarkan hasil penelitian yang telah dijelaskan sebelumnya, maka peneliti mengambil kesimpulan bahwa langkah-langkah yang dilakukan oleh Radio Komunitas Seni Budaya dalam mempertahankan eksistensinya telah berhasil membuat Radio Komunitas Seni Budaya tetap eksis dan bertahan di tengah masyarakat Ujungberung hingga saat ini diantara banyaknya radio komunitas lainnya di Bandung yang sudah tidak beroperasi lagi. Dalam penerapan di Radio Komunitas Seni Budaya terkait dengan strategi pemrograman untuk membuat program-programnya, dari lima strategi pemrograman yang ada, hanya empat strategi pemrograman yang berjalan dengan sempurna. Perlu adanya pembenahan dalam strategi kesesuaian (compatibility). Strategi pemrograman ini dirasa kurang tepat untuk diterapkan di radio komunitas. 


\section{Daftar Putaka}

Effendy, Onong Uchyana. (2009). IImu Komunikasi: Teori dan Praktek. Bandung,Indonesia: CV. Remaja Rosdakarya

Eastman, Susan Tyler dan Ferguson, Douglas A. (2013). Media Programming: Strategies \& Practices. Boston USA: Thomson Wadsworth

Yudhapramesti dan Fadilah. 2011. Media Lokal Sebagai Sarana Pelestarian Budaya Lokal. Library Fikom Unpad.

Masduki. 2005. Perkembangan dan Problematika Radio Komunitas di Indonesia. http://download. portalgaruda.org/article.php?article=130743\&val=5410 